\title{
CZARNE SŁOŃCA, BIAŁE KSIĘ̇̇YCE ŚMIERĆ W SZTUCE ALINY SZAPOCZNIKOW I ANGELIKI MARKUL
}

\section{Katarzyna LEWANDOWSKA (Toruń)}

Śmierci nie można zdefiniować, ponieważ oznacza ona ostateczną pustkę, nieistnienie, które, absurdalnie, wszelkim bytom nadaje istnienie ${ }^{1}$.

Od 12 lub 13 lat zajmuję się pojęciem ciała. Na początku... Ciało w kostnicy, trup. Na początku chciałam się dowiedzieć, co dzieje się z ciałem jako jednostką społeczną po śmierci. Potem zrozumiałam, że kostnica to barometr społeczeństwa. To, co dzieje się w miejskiej kostnicy, dzieje się również na zewnątrz. Kostnica... Tam pracuję, tam jest moja pracownia ${ }^{2}$.

Wystawianie na pokaz i bezczeszczenie ludzkiego ciała, poniżanie jego funkcji i wyglądu, morphings i deformacje, okaleczenia i samookaleczenia.... ból — prawdziwy, przeszywający, niszczący ${ }^{3}$.

Kto kontroluje ciało? ${ }^{4}$

${ }^{1}$ Z. Bauman, Śmierć i nieśmiertelność. O wielkości strategii życia, przeł. N. Leśniewski, Warszawa 1998, s. 6.

2 Teresa Margolles, urodzona w roku 1963, meksykańska artystka. W 1995 roku obroniła dyplom z medycyny sądowej na Uniwersytecie w Meksyku. Współpracowała z grupą SEMEFO Servicio Medico Forense (Forensic Medical Service). Margolles należy do najbardziej radykalnych artystek eksplorujących temat śmierci. Entierro z roku 1999 to pierwsza praca, która została pokazana w Europie. W tej minimalistycznej, niepozornej rzeźbie w formie prostopadłościanu, artystka umieściła zwłoki poronionego, sześciomiesięcznego płodu, ,podarowanego” przez matkę, której nie było stać na tradycyjny pochówek. W 2009 roku Margolles reprezentowała Meksyk na biennale w Wenecji. Historycy sztuki często porównują twórczość Margolles z wiedeńskimi akcjonistami oraz Andreasem Serrano, Valie Export, Orlan, Jeffrey Silverthornemem, Joel-Peter Witkinem; za: Teresa Margolles 127 cuerpos, Kunstverein fur die Rheinlande und Westfalen, Dusseldorf 2006, s. 171.

${ }^{3}$ J. Clair, De Immundo: apofatyczność i apokatastaza w dzisiejszej sztuce, Kraków 2007, s. 8.

${ }^{4}$ N. Triscott, Introduction, [w:] Body Visual, London 1996, s. 5. 
Erekcja i słońce gorszą tak samo, jak trup i mrok piwnic. Ludzkie oczy nie znoszą ani słońca, ani kopulacji, ani trupa, ani zmroku, różnie jednak na ich widok reagują ${ }^{5}$.

Obie artystki szczerze - do bólu i poprzez ból opowiadają o Śmierci. Z rzadka naiwnie i banalnie, czasami poważnie i dotkliwie, często metaforycznie i dosłownie. Śmierć pojawia się w życiu i twórczości tych kobiet wiele razy. Alina Szapocznikow i Angelika Markul — artystki działające w różnych przestrzeniach historyczno-artystycznych poprzez specyficzny, kobiecy język ${ }^{6}$ snują wstrząsającą opowieść. O powolnym zanikaniu, niszczącej destrukcji, wydechu, po którym nie następuje już kolejny wdech.

Jedna z nich przeszła wojenne piekło tracąc najbliższych, walcząc o swoje przetrwanie wyrywała rzeczywistości momenty intensywne, które miały na nią działać jak leczniczy balsam. Gryząc do krwi paznokcie, spijała z nich nektar nieśmiertelności, czując ból nie do zniesienia, okrywała się woalem przyjemności. Drapiąc z wściekłości swoje dziewczęce a później kobiece ciało wlewała w te głębokie, gnijące rany drogocenne lekarstwa. Długo milczała, przygryzając usta. Długo milczała przesłaniając pięknym, zmysłowym uśmiechem opowieść o Śmierci. I nagle, kiedy rak zaatakował jej pierś, zaczęła tkać dwuwątkową tkaninę z figuralnym przedstawieniem Erosa i Tanatosa - w seksualnym zespoleniu - nierozłączni o niezwykle pięknych i przerażających twarzach, zachłanni na życie artystki. Obaj bogowie zżerali jej umysł, tworząc seksualno-perwersyjne fantazmaty, nigdy nie spełnione. Powstawały jakieś chwiejne konstrukcje myślowe, które prowadziły do zupełnego upadku. Umysł zakrapiany morfiną postrzegał rzeczywistość fałszywie, łapał byty, które nie istniały, były iluzoryczne i fałszywe. A jednak należały do niej — były wyłącznie jej wytworami. Mogła za nimi podążać, trzymać w zaciśniętych rękach, odtwarzać w rzeźbie, a kiedy zechciała również je zniszczyć.

Druga tworzy teraz, spełnia się jako artystka — 'Kreatura', eksperymentując sama ze sobą, widzem oraz materiałem, który wykorzystuje podczas tej niezwykle intymnej — kobiecej kreacji ${ }^{7}$. Ta specyficzna intymność często perwersyjna, bezlitośnie wdziera się wszystkimi porami w ludzkie ciało. Artystka bezwzględnie przytrzymuje widza za włosy, aby ten nasycił wszystkie swoje zmysły koszmarnym, pełnym obrzydliwości bytem, którego kreatorką jest O n a — kobieta i artystka. Jej niezwykłe, monstrualne instalacje i obrazy wideo stają się jakby szorstkim sznurem, który silnie zaciska się na szyi oglądającego, zostawiając siną pręgę. Śmierć w sztuce Angeliki Markul stanowi podstawę do konstruowania dalszych narracji, jest punktem wyjściowym dla opowieści, które przybierają formę wielowarstwowej pajęczyny, oplatającej bezbronnego widza. Umieranie dla artystki jest początkiem i końcem - kolokwialnie, lecz prawdziwie rzecz ujmując. W warstwie dosłownej jest to rzeczywisty proces, w którym zanika życie, natomiast w przestrzeni symbolicznej powstają nowe opowieści, światy, fenomeny, które Angelika Markul przekłada na artystyczny dyskurs. Wprowadza widza w przestrzenie teatralne, makabryczne, rozchwiane. Żadnej równowagi, żadnego ukojenia.

${ }^{5}$ G. Bataille, Stoneczny odbyt, przeł. Bogdan Banasiak, [on-line]. [Dostęp: styczeń 2013]. Dostępny w WWW: http://bb.ph-f.org/przeklady/bataille_odbyt.pdf.

${ }^{6}$ Czym jest język kobiecy? Czy w ogóle istnieje język kobiecy? Francuska filozofka feministyczna, teoretyczka i krytyczka literatury, pisarka, poetka i dramatopisarka Hélène Cixous stworzyła termin écriture féminine, którym próbuje opisać specyfikę kobiecego języka. Tym problemem również zajmowała się inna francuska myślicielka Luce Irigaray, która wskazywała na wyraziste różnice pomiędzy tym, co kobiece a tym, co męskie.

${ }^{7}$ Angelika Markul korzysta z niezwykle charakterystycznego repertuaru form: łączy obrazy wideo z instalacjami, do których budowy używa szkła, drewna, czarnej folii, lamp o drażniącym oczy świetle czy przemysłowych wentylatorów. 
Anne Laure Stolz pisze:

Angelika Markul jest artystką-wizjonerką. Z okiem artysty wideo, zawsze ma się na baczności i przypatruje się codziennemu życiu i światu, który ją otacza, w nieustannym poszukiwaniu obrazów. Z niekwestionowanym zapałem do pracy, używa te obrazy, które czasami są prostymi szkicami, a czasami skończonymi filmami wideo, do swoich prac i refleksji ${ }^{8}$.

Michał Jachuła natomiast stwierdza, że artystka dąży „do odczuwania i chłonięcia różnymi zmysłami atmosfery lęku i niepokoju, stanów zawieszenia, niedopowiedzeń czy momentów krytycznych" .

Szczegółowy opis będzie dotyczył kilku wybranych prac, w których obie artystki silnie eksplorują Śmierć - opisując ją wszystkimi zmysłami i oczekując również od odbiorcy aby wszedł $\mathrm{w}$ tę sensualną i nieprzyjemną, ale zapewne oczyszczającą grę ${ }^{10}$. Wybrane obiekty stanowią bezpośrednio wizualne przedstawienie Śmierci. Zdarza się, że czasami same znikają, ponieważ właśnie takie było założenie artystek. Zostały wykorzystane nietrwałe materiały do ich stworzenia, za chwilę znikną, forma stanie się pustką.

Cała sztuka jest mistyfikacją, mniej lub bardziej inteligentnym kłamstwem, ale w przypadku Aliny Szapocznikow i Angeliki Markul jakby nie do końca. Nierealność wpełza w realność. Rzeczywistości nakładają się na siebie. Kolejne warstwy przenikają się, nie ma początku i nie ma końca i tym samym nie ma stałego punktu odniesienia. Śmierć, rozkład, smród, strach, niepewność, wykluczenie to podstawowe elementy, które budują specyficzny, estetyczno-etyczny język wykorzystany przez obie artystki. Ich sztuka staje się „najintymniejszą intymnością”, ponieważ bezwstydnie, ale i niezwykle świadomie obnażają siebie same, snując opowieść o tym aspekcie życia, który jest nieunikniony, tajemniczy, smutny i fascynujący.

Nie jestem w stanie jej doświadczyć, a gdy raz ją napotkam, to już nigdy o niej nie opowiem $^{11}$.

Alina Szapocznikow i Angelika Markul to artystki do bólu (w dosłownym tego słowa znaczeniu) autentyczne. Działania artystyczne w bardzo świadomy i w bardzo nie-delikatny sposób dostosowują — wydaje się — do słów Georga Maciunasa: życie bywa sztuką a sztuka życiem. Obie uprawiają twórczość przepełnioną estetyką śmier$\mathrm{ci}^{12}$, która próbuje wydobyć na światło dzienne, jak pisał Zygmunt Bauman:

rzeczy okrutne i krwawe, [...] odrażające odpryski rzeczywistości, które ogłosiliśmy, że nie istnieją lub są niewyrażalne ${ }^{13}$.

\footnotetext{
${ }^{8}$ K. Sienkiewicz, Angelika Markul, [on-line]. [Dostęp: styczeń 2013]. Dostępny w WWW: http:// www.culture.pl/baza-sztuki-pelna-tresc/-leo_event_asset_publisher/eAN5/content/angelika-markul.

${ }^{9}$ Tamże.

${ }^{10}$ W przypadku Angeliki Markul opis będzie dotyczył wystawy „Nów”, która odbyła się w 2009 roku w toruńskim CSW. Autorkę interesuje przede wszystkim instalacja site specific zaprezentowana w największej sali wystawienniczej. Wydaje się, iż praca ta stanowi esencję tematu podjętego w tym artykule przez autorkę.

${ }^{11}$ Z. Bauman, Śmierć i nieśmiertelność, s. 7.

${ }^{12}$ Inne artystki, które podejmowały lub podejmują brutalne przedstawienie śmierci to między innymi: Frida Kahlo, Hannah Wilke (Intra-Venus), Helen Chadwick (Unnatural Selection), Carolee Scheemann (Viet Flakes, 1965), Orlan, Natalia LL (Destrukty), Valie Export, Magda Moskwa, Katarzyna Kozyra, Zuzanna Janin, Teresa Margolles, Regina Galindo, Sally Mann, Francesca Woodmann, Kiki Smith, Zoe Leonard.

${ }^{13}$ Z. Bauman, Śmierć i nieśmiertelność, s. 145.
} 
Paweł Leszkowicz analizując twórczość dwóch znakomitych, już nieżyjących artystek - Hannah Wilke i Helen Chadwick, uważa i wydaje się to być prawdziwą tezą:

iż kobiety są bardziej otwarte i bliższe ciału, ze względu na ich intensywniejszy kontakt z jego wnętrzem: poprzez doświadczenie menstruacji i porodu, jak i ,rozproszony” charakter kobiecego erotyzmu i wewnętrzną naturę kobiecego orgazmu ${ }^{14}$.

Kobietom-artystkom łatwiej mówić o tych aspektach człowieczeństwa, które bezpośrednio łączą się z cielesnością, z ciałem. Wybierają prawie zawsze opowieść o ciele chorym, kalekim, upośledzonym, bolesnym, wadliwym, starym, zniszczonym i w końcu umierającym. Cielesność staje się jeszcze bardziej cielesna, mięsna, prawdziwa. To, co dawniej należało do dyskursu medycznego, było szczelnie zamknięte w szpitalu, kostnicy czy prosektorium dzisiaj jest re pre ze n tow an e lub pre zentowane w galeriach i muzeach. Kostnica stała się swoistą pracownią, miejscem dla artystek i artystów ${ }^{15}$. Sztuka przestała kształcić i radować umysł (docere et delectare) tak jak chciał św. Bonawentura ${ }^{16}$. Idealne platońskie piękno pochodzace od samego stwórcy zniknęło w skatologicznej estetyce. Ni e s m a k zastąpił s m a $\mathrm{k}^{17}$. Sztuka stała się niezwykle sensualna, jest niepokojąca, momentami odpychająca; to przestrzeń na granicy rozpadu, od którego widz najchętniej odwróciłby wzrok, ale nie może, ponieważ równocześnie budzi się w nim zachłanność do oglądania tych lepkich i brudnych miejsc przesiąkniętych Śmiercią.

Leontios, idąc z Pireusu na górę pod zewnętrzną stronę miejskiego muru:

[...] zobaczył trupy leżące koło domu kata. Więc równocześnie i zobaczyć je chciał, i brzydził się, i odwracał, i tak długo walczył z sobą i zasłaniał się, aż go żądza przemogła i wytrzeszczywszy oczy przybiegł do tych trupów [...]. „No, macie teraz, wy moje oczy przeklęte, napaście się tym pięknym widokiem" ${ }^{\text {"18 }}$.

Baumanowskie „odpryski rzeczywistości” zostają konsekwentnie i bezpardonowo wyciągane na zewnątrz. Artystki, które uprawiają sztukę abjectu ${ }^{19}$ - raczą widza okrutnymi 'obrazami nie do wyobrażenia' zmuszając, aby ten smakował ją wszystkimi swoimi zmysłami. Oko już nie wystarcza.

Należą do nich Alina Szapocznikow i Angelika Markul.

\section{Alina Szapocznikow — Pierwsza}

Alina Szapocznikow była jedną z najważniejszych rzeźbiarek XX wieku. Innowacyjna, eksperymentująca, poszukująca, wielka artystka. Uznana za prekursorkę sztuki kobiecej, a uszczegółowiając, sztuki feministycznej.

\footnotetext{
${ }^{14}$ P. Leszkowicz, Hannah Wilke i Helen Chadwick: sztuka w obliczu medykalizacji, Magazyn Sztuki 1996 nr 4 s. 88.

${ }^{15}$ Teresa Margolles pracuje z trupami. Nieżywe ciało ludzkie stało się dla artystki materiałem do pracy. Swoje atelier artystyczne przeniosła do kostnicy miejskiej i prosektorium w Meksyku.

16 J. Clair, De Immundo, s. 8.

${ }^{17}$ Tamże; autor w kontekście tych dwóch kategorii przywołuje nazwiska artystów: Lucio Fontana, Louise Bourgeois, Orlan, Andreas Serrano, Otto Muehl, David Nebreda.

${ }^{18}$ Platon, Państwo, księga IV, przeł., wstępami i objaśnieniami opatrzył W. Witwicki, Warszawa 2010, s. 185.

${ }^{19}$ Abject jest niepokojące, gdyż to, co już odrzucone, nie jest ani podmiotem, ani przedmiotem, ale sytuuje się pomiędzy nimi, przez co właśnie staje się wstrętne i niebezpieczne. Natura abject jest nieokreślona, niejasna, kleista, kalająca i zdecydowanie nieuporządkowana; por.: Hal Foster, Monika Bakka, Julia Kristeva, Izabela Kowalczyk.
} 
Zaczęto dostrzegać głównie kształty maciczne, waginalne, skrupulatnie liczyć ilość piersi, roztrząsać prawdziwe znaczenie i umiejscowienie warg. Z konferencji [...] zdominowanej właśnie przez taką wykładnię — kolejno wychodzą podirytowani panowie ${ }^{20}$.

To czy nazwiemy Szapocznikow feministką — ze względu na czas, kiedy tworzyła, należałoby pewnie mówić proto-feministką — nie ma znaczenia ${ }^{21}$.

Alina Szapocznikow w pewnym momencie zamieniła życie w sztukę a sztukę w życie. Te dwie przestrzenie zaczęły nachodzić na siebie tworząc niezwykłą hybrydę, z jednej strony fascynującą, z drugiej zaś przerażającą. W obszar sztuki wkradał się powoli I n n y — niebezpieczny, niszczący, nieobliczalny. Nowotwór zaatakował piękne ciało artystki, bezlitośnie zjadając jej wnętrzności, zmiany następowały szybko. I ona wykorzystała tę chorobę stwarzając osobisty język form dla oddania niszczącej metamorfozy, którą przechodził coraz to bardziej wyniszczony organizm. W latach 1969-1972 powstały prace, które stanowią swego rodzaju wizualne archiwum choroby artystki. Utrwaliła w nich swoje cierpienie, strach, ból, chęć życia i w końcu zupełną niemoc. Poprzez uzewnętrznienie tego, co pod skórą, tego, co ukryte - w tym przypadku komórek rakowych — Szapocznikow podejmuje nierówną walkę z chorobą. Otwiera swoje ciało, staje się chirurgiem, który precyzyjnym cięciem skalpela wyżyna zarażoną tkankę. Ta wizualna penetracja pozwala artystce zdemaskować chorobę, ,przebrać” ją za dzieło sztuki i mieć na chwilę — (bo tylko w trakcie aktu twórczego), nad nią władzę. Wymyślać dla niej formę czy czas istnienia — artystka w każdym momencie może zniszczyć swoje dzieło. Tylko wyłącznie ona jest odpowiedzialna za to, co stwarza.

\section{Pamiątka I. Pogrzeb Aliny. O kilku śmierciach}

Pamiątki (1967-1970) dla Aliny Szapocznikow miały bez wątpienia charakter terapeutyczny, być może jednak również i destrukcyjny. Choroba artystki zmusiła ją do powtórnego przejścia przez wojenne piekło (Holocaust effect) ${ }^{22}$, które konsekwentnie przez lata było wypierane i zapominane.

Wybacz, wstydzę się za to. Wiesz, jak nie znoszę, jak brzydzę się tych ludzi, którzy wypominają sobie, czy „chwalą” się latami męki, jaką przeżyli ${ }^{23}$.

Bardzo pragnąłem dowiedzieć się, czegoś bliżej o jej pobycie w hitlerowskim obozie w Oświęcimiu, o którym nigdy nie mówiła. Był to dla niej temat tabu [...]. Wręcz obsesyjnie unikała o tym rozmowy ${ }^{24}$.

${ }^{20}$ K. Czerni, Drugie skrzydto albo Aliny Szapocznikow sen o lataniu, [w:] Zatrzymać życie: Alina Szapocznikow. Rysunki i rzeźby, [katalog wystawy] IRSA Fine Art. Gallery, red. J. Grabski, Kraków-Warszawa 2004, s. 18-19.

${ }^{21}$ A. Jakubowska, Portret wielokrotny dzieła Aliny Szapocznikow, Poznań 2008, s. 17; Ciekawostką może być fakt, że tekst Szapocznikow Korzenie mojej twórczości wyrastaja z zawodu rzeźbiarza został opublikowany na tylnym skrzydełku okładki jednego z numerów feministycznego pisma „Cahiers du Grif”. Informacja pochodzi od redaktorki tego pisma Françoise Collin; A. Jakubowska, Portret wielokrotny, s. 17.

22 „W takich momentach Holocaust nie jest re-prezentowany, ale raczej prezentowany lub ponownie odegrany"; E. van Alphen, Caught by History. Holocaust Effects in Contemporary Art, Literature, and Theory, Stanford 1997; cyt. za: A. Jakubowska, Portret wielokrotny, s. 216.

${ }^{23}$ Fragmenty listów Aliny Szapocznikow do Ryszarda Stanisławskiego (1948-1959), [w:] Alina Szapocznikow 1929-1973, [katalog wystawy] Galeria Sztuki Współczesnej Zachęta, Warszawa 1988; cyt. za: A. Jakubowska, Portret wielokrotny, s. 97.

${ }^{24}$ A. Wojciechowski, ***, [w:] Zatrzymać życie. Alina Szapocznikow. Rysunki i rzeźby, red. J. Grabski, Kraków-Warszawa 2004; cyt. za: A. Jakubowska, Portret wielokrotny, s. 206. 
Zestawiała ze sobą kontrasty; swoje przedwojenne zdjęcie - uśmiechniętej dziewczynki, pełnej energii, radości i poczucia bezpieczeństwa z trupem kobiety — być może więźniarki obozu w Auschwitz ${ }^{25}$, bezimiennej, pozbawionej tożsamości Istoty. W Pamiątce I (1971) artystka buduje wielopiętrową konstrukcję o śmierci. Zatapia w nieregularnych bryłach żywicy dwa zdjęcia. Nagi trup leży, jakby na ziemi, zupełnie bezwładny. Wychudzona twarz jest silnie zdeformowana z szeroko otwartymi ustami i wyszczerzonymi zębami - Śmierć. I obok zdrowa dziewczynka, buńczucznie patrząca w obiektyw, pewna siebie, dominująca - Życie.

Jest jeszcze jedna postać w tej wizualnej opowieści. Ojciec Aliny Szapocznikow, którego obraz artystka wycięła. Agata Jakubowska argumentuje tę decyzję tym, iż zmarł on na gruźlicę przed wojną, nie doświadczył „nie wyobrażonego” — a więc nie ma dla niego miejsca w kolekcji specyficznych pamiątek rzeźbiarki. Ojciec reprezentuje również męski punkt widzenia — in n y od kobiecego. A przecież Szapocznikow przeżyła gehennę wojenną głównie z kobietami, pośród nich.

Pamiątka $I$ wessała $\mathrm{w}$ siebie kilka historii, rozgrywających się w różnym czasie, ale które bezpośrednio dotyczą artystki w jej życiowych, granicznych momentach. Zostały pochłonięte przez żywicę, która swoją fakturą i kolorem przypomina ludzką skórę. Dotykając odczuwa się zimno, nierówności. Ta rzeźba — twór — Inny — rak — stała się dowodem końca życia ludzkiego, rozpadu, ale jednocześnie dowodem przeciw ostatecznemu ,przemieleniu” i zniknięciu ciała.

Inną rzeźbą Aliny Szapocznikow chwytającą śmierć jest monumentalny Pogrzeb Aliny z roku 1970 (il. 48). Artystka stworzyła grobowiec, rodzinny, duży, dla wszystkich. Dla siebie również. Zdeformowany, przypominający mięsną tkankę z wieloma naroślami, chorą, zepsutą, zdegenerowaną. W grobowcu leżą już najbliżsi rzeźbiarki. Wtopiła wiele zdjęć. Nie ma jeszcze tylko Gospodyni, bo przecież to przede wszystkim JEJ grobowiec, to JEJ pogrzeb - ALINY.

Izabela Kowalczyk zauważa, ,iż używanie fotografii w rzeźbach jest też ciekawe ze względu na związki samej fotografii ze śmiercią" "26. Przywołuje Rolanda Barthes'a:

Zdjęcie tak podobne, że usiłuje się je ożywić [...] — jest jak teatr pierwotny, jak Żywy Obraz, uosobieniem nieruchomej i pomalowanej twarzy, pod jaką kryją się dla nas umarli ${ }^{27}$.

Nadając pracy taki tytuł, Alina Szapocznikow sama siebie uśmierca, symbolicznie — ponieważ każde potknięcie, niepokój, zmiana, cierpienie jest swego rodzaju śmiercią. Każda istota czująca przeżywa w życiu wiele swoich śmierci. Jednak w kontekście choroby artystki i wiedzy jakie były konsekwencje raka, Pogrzeb Aliny staje się narracją jak najbardziej prawdziwą i dosłowną. Albowiem zapomnienie o śmierci kaleczy nasz umysł, jak pisał Zygmunt Bauman. I należy o niej myśleć z szacunkiem, bez strachu, być gotowym. Próbować ją oswoić lub oswoić siebie z nią. Przepracować Obcego w sobie, nadać mu tożsamość, twarz, jakąś formę. Susan Sontag, która sama zachorowała na raka i przez niego zmarła, pisała:

w sensie metaforycznym [rak] jest nie tyle chorobą czasu, co chorobą lub patologią przestrzeni. Główne jego metafory nawiązują do pojęć z zakresu topografii (rak ,rozszerza się”, ,rozprzestrzenia”; guzy są „,usuwane drogą chirurgiczną”) i jego najbardziej

${ }^{25}$ J. Gola, Katalog rzeźb Aliny Szapocznikow, [Muzeum Narodowe w Krakowie], Kraków 2001, s. 10 .

${ }^{26}$ I. Kowalczyk, Aliny Szapocznikow: oswajanie „abjectu”, [on-line]. [Dostęp: styczeń 2013]. Dostępny w WWW: http://www.obieg.pl/artmix/4152.

${ }^{27}$ R. Barthes, Światło obrazu. Uwagi o fotografii, przeł. J. Trznadel, Warszawa 1996, s. 55. 
przerażająca konsekwencją, oprócz samej śmierci, jest okaleczenie lub amputacja jakiejś części ciała ${ }^{28}$.

\section{Angelika Markul — Druga}

Poszukując własnego idiomu artystycznego ta młoda, niezwykle inteligentna artystka wykorzystuje, z jednej strony, wielopłaszczyznową metaforę, a z drugiej, zmierza do symplifikacji przekazu boleśnie (dosłownie) jednoznacznego. Angelika Markul - uczennica Christiana Boltańskiego, jednego z najważniejszych współczesnych, intermedialnych artystów, wytrwale i konsekwentnie opowiada o granicach pomiędzy życiem i śmiercią, obecnością i nieobecnością, stawaniem i zanikaniem, wyobraźnią i rzeczywistością. W sztuce eksploruje momenty graniczne, w których dochodzi do zupełnej destrukcji ducha, ciała, umysłu.

Następuje szybsze bicie serca, krew bębni w żyłach. Ta niewiadoma jest paraliżująca, ponieważ widz nie jest niczego pewien, zatrwożony czeka na następną chwilę, która może okazać się dla niego jeszcze bardziej bolesna od poprzedniej. Trwałe (?) 'ja' ginie gdzieś, rozsypuje się, znika. Artystka bez żadnych skrupułów zaprasza Śmierć w przestrzenie muzealno-galeryjne. Momentami jest Ona koszmarna, odpychająca, wstrętna, innym razem liryczna, poetycka, spokojna.

Angelika Markul opowiada o Śmierci w szerokim kontekście, nie jest to umieranie zindywidualizowane, raczej doświadczenie wszystkich czujących istot. Świat roślin, zwierząt i ludzi przeplata się ze sobą. Każda z tych egzystencji traktowana jest przez artystkę w ten sam sposób - ponieważ Śmierć dotyka wszystkich i wszystko. Artystka tworzy odrażająco-perwersyjno-bolesny kolaż, w którym tematami przewodnimi są: pamięć, wspomnienie, doświadczenie, historia oraz życie kończące się zawsze umieraniem, po którym znowu następuje powtórne narodzenie.

\section{Nów — opowieść o Nocy, Dakini i Śmierci}

Nów Angeliki Markul pokazany w 2009 roku w Centrum Sztuki Współczesnej w Toruniu był szeroką prezentacją prac artystki (il. 51). Przestrzeń wystawiennicza stała się gigantyczną instalacją, złożoną z wcześniejszych prac wideo, rzeźb oraz imponującego obiektu site specific, zaprojektowanego przez artystkę do największej sali ekspozycyjnej. Ta instalacja bezpośrednio odwoływała się do estetyki śmierci. W sposób dosłowny eksplorowała motyw śmierci — pomijając niuanse i tabuizację umierania oraz pośmiertnego rozkładu. Angelika Markul zamieniła sterylną przestrzeń architektoniczną w wielkie cmentarzysko, po którym biegają nagie, zdeformowane istoty płci żeńskiej, wysmarowane krwią, tłuszczem i popiołem. Wielka Kobieta, Wielka Matka ciężko oddycha, prowokując swój orszak do szaleńczego, histerycznego tańca życia i śmierci. To świat zmarłych, agonalne przyspieszenie, pochłaniająca otchłań, wegetatywność, która uwodzi i zatruwa, usztywniona, monumentalna groza tego, czego nie da się uniknąć.

Nów jest jedną z faz księżyca, w której nie można zobaczyć go z Ziemi nieuzbrojonym wzrokiem, zwrócony ku niej nieoświetloną półkulą paradoksalnie uwidacznia, czyni ewidentną swoją własną niewidzialność. Nów w nieomal wszystkich kulturach i w mitologiach związany jest z żeńskością, misterium owulacji, potencjałem wzrostu i zmiany w rytmach miesięcznych cykli. Wielka Kobieta/Matka — Istota Pierwotna, Ona, Prymarna Podstawa — Rodzicielka — Zabójczyni staje się główną postacią.

${ }^{28}$ S. Sontag, Choroba jako metafora. AIDS i jego metafory, przeł. J. Anders, Warszawa 1999, s. 18. 
Ma moc rodzenia. Żeńskość spontanicznie rodzi. Jest podstawową przestrzenią i pustką ${ }^{29}$.

Ta dobra i ta zła kobieta/matka.

Biegun pozytywny zbiera takie cechy, jak matczyna troskliwość i współczucie; magiczny autorytet żeńskości; mądrość i duchowy zachwyt, które przerastają rozum; instynkt czy impuls opieki; wszystko, co jest łagodne, wszystko, co pielęgnuje i podtrzymuje, co przyspiesza wzrost i płodność. Krótko mówiąc — dobra matka.

Negatywny biegun przywodzi na myśl złą matkę: wszystko, co tajemne, ukryte, ciemne; otchłań, świat zmarłych, wszystko, co pożera, uwodzi i truje oraz wszystko to, co jest przerażające i czego nie da się uniknąć, jak losu ${ }^{30}$.

Kobieta tworzy bezkształtność. Przynajmniej w męskich fantazmatach. Jest chaosem, ziejąca otchłanią, ciemnością, wilgocią. Ale kobieta tworzy także dziecko? Jak zatem połączyć dziecko z bezkształtnością? Miłość z nienawiścią? Życie ze śmiercią? Artystka inteligentnie zadaje pytania nie udzielając odpowiedzi. Te dychotomie są nierozdzielne, inne i takie same, całkowicie zależne od siebie.

Instalacja site specific składała się z kilku znaczących elementów: wielkoformatowych rzeźb oraz specyficznych, nerwowo drgających obrazów. Gigantyczne obiekty artystka zbudowała z czarnej, połyskującej, pięknie udrapowanej folii, rozpiętej na drewnianych stelażach. Widz zastanawia się kogo spotkał? Kto to jest? Noc? Demonica? Śmierć? Żałobna Kobieta? Obiekt zostaje ucieleśniony, przyjmuje rolę niepokojąco niebezpiecznej kobiety. To taka Maman ${ }^{31}$, która posiadła wiedzę i władzę, z góry przyglądając się światu. Wchłaniając w siebie - pod czarną spódnicę istoty, które powinny już odejść ze świata żywych. Bezwstydnie rozwiera uda, dając i zabierając życie, budując je i niszcząc.

Niektóre z form zostały przez artystkę jakby „wciśnięte” w drewniane skrzynie trumny. Ale są nieposłuszne. Wylewają się na zewnątrz, żyją swoim własnym życiem, kierują się tam, gdzie chcą. Zachowane, zapakowane w czarne worki zwłoki — resztki zostały porzucone, stały się abjectem — wciąż pomiędzy, jeszcze nie pochowane, czekające na swoją kolej. Treść bez jakichkolwiek dodatków.

Drgające obrazy to srebrne ekrany oświetlone pulsującym światłem, które bezwzględnie atakuje wpatrujące się weń oko. Ten obraz męczy, wywołuje ból, denerwuje. To jakby moment między jednym a drugim mrugnięciem powieki, przebłyski czegoś, co jest nieznane i niezrozumiałe. Jakaś zaszyfrowana wiadomość, zapewne bardzo ważna, ale my nie potrafimy odczytać tego ukrytego znaku. Widz odczuwa jedynie niewiarygodne zmęczenie.

Przestrzeń ta jednoznacznie kojarzy się z miejscem ,przeklętym”, kostnicą, przemocą, pochówkiem, piekłem, gehenną, mroczną tajemnicą, śmiercią.

I brakiem wyjścia.

${ }^{29}$ T. Allione, Kobiety mądrości. Tajemne życie Maczig Labdron i innych Tybetanek, Kraków 1998, s. 58.

${ }^{30}$ C. G. Jung, The Archetypes and the Collective Unconscious, transl. by R. F. C. Hull, Princeton, N.J. 1968, s. 158 („Collected Works”, wol. 9, cz. 1).

${ }^{31}$ Tytuł rzeźby francuskiej artystki Louise Bourgeois. „Pajęczyca jest odą do mojej matki. Ona była moją najlepszą przyjaciółką. Jak pajęczyca, moja matka była tkaczką. Jak pajęczyca, moja matka była bardzo mądra. Pająki są przyjazne. Pająki jedzą komary. Wiemy, że komary roznoszą choroby, dlatego są niechciane. Tak, pająki są pomocne i opiekuńcze, tak jak moja matka"; U. Usakowska-Wolff, Niepokój w starych dekoracjach, [on-line]. [Dostęp: maj 2013]. Dostępny w WWW: http://www.usakowska-wolff.com/bourgeois.htm. 


\section{Zakończenie}

One przybywają z daleka: spoza czasu, z pustkowia, gdzie wiodą swój żywot czarownic, spod spodu, spod „kultury”, z dzieciństwa, tak bolesnego, że trzeba je zapomnieć, pogrzebać w niepamięci. Małe dziewczynki uwięzione w ,źle wychowanych” ciałach. Pełne rezerwy, niedostępne nawet same dla siebie, zimne jak głaz. Nieczułe. Ale cóż się pod tym kłębi! $!^{32}$

$$
* * *
$$

Alina Szapocznikow (ur. 16 maja 1926 w Kaliszu, zm. 2 marca 1973 w Praz-Coutant, Francja). Jedna z najwybitniejszych polskich rzeźbiarek. W latach 1945-1946 studiowała w praskiej pracowni Otokara Velimskiego. Dalsze studia odbyła w Wyższej Szkole Artystyczno-Przemysłowej w Pradze (pod kierunkiem Josefa Wagnera) i w latach 1948-1950 w École Nationale Supérieure des Beaux-Arts (ENSBA) w Paryżu (jako wolna słuchaczka uczęszczała do pracowni Paula Niclausse’a). W 1951 roku wróciła do Polski. W roku 1963 przeniosła się na stałe do Francji. Twórczość Szapocznikow była na bieżąco żywo komentowana. Kilkakrotnie artystka otrzymała nagrody za swoje prace: w roku 1965 na XXI Salonie Majowym w Paryżu pokazała rzeźbę Goldfinger, za którą uhonorowano ją nagrodą Fundacji Copley (w jury byli między innymi: Jean Arp, Marcel Duchamp, Max Ernst); w roku 1972 na II Międzynarodowej Wystawie Rysunku w Moderna Galerija w Rijece wyróżniono ją za serię rysunków Ludzka droga (w jury zasiadali: Pierre Alechinsky, Alexander Calder, Joan Miró, Antonio Tapies). Pierwszą obszerną prezentacją twórczości tej wybitnej rzeźbiarki poza Polską była wystawa „Alina Szapocznikow: Sculpture Undone 1955-1972” w Centrum Sztuki Współczesnej WIELS w Brukseli (wrzesień 2011 - styczeń 2012). Pokaz skupiał się na pracach Szapocznikow z najbardziej eksperymentalnego, późnego okresu jej twórczości, któremu kres położyła przedwczesna śmierć artystki. Ekspozycja stanowiła część pierwszą „Culture” — Programu Kulturalnego Prezydencji Polskiej w Radzie Unii Europejskiej. Po premierowej odsłonie w Brukseli była pokazywana także m.in. w Los Angeles i Nowym Jorku (2012) $)^{33}$.

Angelika Markul (ur. 1977 r. w Szczecinie, mieszka i pracuje w Paryżu). Artystka ukończyła studia wyższe w École Nationale Supérieure des Beaux Arts w Paryżu, seminarium „Introduction to the exhibition” oraz otrzymała Dyplom Narodowy Sztuk Plastycznych w ENSBA w dziedzinie sztuk multimedialnych. W ciągu ostatnich lat uczestniczyła w wielu wystawach zbiorowych i indywidualnych w Europie m.in. „La Clarté Souterraine” Kewenig Galerie, Kolonia, 2007/2008 (wystawa indywidualna); „Parole d'insecte”, Galerie Frédéric Giroux, Paryż, 2006 (wystawa indywidualna); „The Pantagruel Syndrome” w ramach T1 Torino Triennale Tremusei - Castello di Rivoli, Museo d'Arte Conteporenea w Turynie, 2006; „J'en rêve” w Fondation Cartier w Paryżu, 2005; „I still believe in miracles” w Musée d'Art Moderne de la Ville de Paris, 2005. W Polsce wystawiała wielokrotnie, m.in. w ramach wystawy indywidualnej w Galerii Foksal w Warszawie w 2006 r., „Ponowoczesność i życie wieczne”, Galeria Miejska Arsenał, Poznań 2007; „Pamięć tej chwili z odległości lat, które miną”, Fabryka Schindlera, Kraków 2007. Wystawa indywidualna w Centrum Sztuki Współ-

${ }^{32}$ H. Cixous, Śmiech Meduzy, [w:] Ciało i tekst. Feminizm w literaturoznawstwie - antologia szkiców, red. A. Nasiłowska, Warszawa 2001, s, 170 („Biblioteka Tekstów Drugich”, t. 1).

${ }^{33}$ M. Kitowska-Łysiak, Alina Szapocznikow, [on-line]. [Dostęp: styczeń 2013]. Dostępny w WWW: http://www.culture.pl/baza-sztuki-pelna-tresc/-/eo_event_asset_publisher/eAN5/content/ alina-szapocznikow. 
czesnej Zamek Ujazdowski w Warszawie. Projekt „Bambi w Czarnobylu” wyróżniony nagrodą SAM Art Projects 2012. Markul otrzymała 20 tys. euro na realizację projektu, który zostanie wystawiony w Palais de Tokyo w Paryżu. W galerii Tarasieve trwa aktualnie wystawa najnowszych prac Markul. Artystka przygotowuje ponadto wystawy osobiste: w Zamku Chamarande we Francji (marzec 2013) i w Muzeum Sztuki w Łodzi (jesień 2013). Weźmie także udział w przyszłorocznej edycji nowojorskiego biennale Performa ${ }^{34}$.

\section{BLACK SUNS, WHITE MOONS-DEATH IN THE ART OF ALINA SZAPOCZNIKOW AND ANGELIKA MARKUL}

Both of the artists are painfully honest, and through pain, they talk about death. Rarely ever is it naïve and trivial, sometimes it is serious and acute, frequently it is metaphorical and literal. Death reoccurs in the lives and works of these two women quite often. Alina Szapocznikow and Angelika Markul - two artists operating within different historical-artistic spaces-they tell a shocking tale in a specific feminine language. The tale of slow vanishing, crushing destruction, about that exhalation which is not followed by another inhalation.

KEY WORDS: Feminist art; feminine language; illness; death; sculpture; installation.

${ }^{34}$ J. Zielińska, [Wstęp], [w:] Nów. Angelika Markul, [katalog wystawy] Centrum Sztuki Współczesnej w Toruniu, 20 marca - 31 maja 2009, [on-line]. [Dostęp: styczeń 2013]. Dostępny w WWW: http://csw.torun.pl/wystawy/baza-wystaw/angelika-markul. 